\title{
Adding an empirical factor to better represent the rewetting pulse mechanism in a soil biogeochemical model
}

\author{
Xuyong Li ${ }^{\mathrm{a}, *}$, Amy E. Miller ${ }^{\mathrm{b}}$, Thomas Meixner ${ }^{\mathrm{c}}$, Joshua P. Schimel ${ }^{\mathrm{d}}$, John M. Melack ${ }^{\mathrm{d}}$, James O. Sickman ${ }^{\mathrm{e}}$ \\ a State Key Laboratory of Urban and Regional Ecology, Research Center for Eco-Environmental Sciences, Chinese Academy of Sciences, Beijing 100085, China \\ b National Park Service, Anchorage, Alaska 99501 USA \\ c Department of Hydrology and Water Resources, University of Arizona, Tucson, AZ 85721, USA \\ d Department of Ecology, Evolution and Marine Biology, University of California, Santa Barbara, CA 93106, USA \\ e Department of Environmental Sciences, University of California, Riverside, CA 92521, USA
}

\section{A R T I C L E I N F O}

\section{Article history:}

Received 2 April 2010

Received in revised form 31 August 2010

Accepted 7 September 2010

\section{Keywords:}

Rewetting pulse

Mineralization

Carbon and nitrogen cycling

Moisture factor

DAYCENT

\begin{abstract}
A B S T R A C T
The rewetting of a dry soil causes a pulse in decomposition of soil organic matter (SOM). This mechanism may dominate carbon $(\mathrm{C})$ and nitrogen $(\mathrm{N})$ cycles in arid, semi-arid and Mediterranean ecosystems. Existing biogeochemical models perform poorly for systems characterized by pulsed events. In this study, we added a rewetting factor into the DAYCENT soil biogeochemical model to better represent the drying-rewetting pulses. Based on a 4-month laboratory incubation from a parallel study, we developed a simple rewetting factor for representing the enhanced mineralization pulse by rewetting stimulation. The rewetting factor was then incorporated into DAYCENT by modifying the soil moisture factor. The DAYCENT modification significantly improved model performance in predicting soil $\mathrm{C}$ respiration rates in drying-rewetting treatments through the capture of rewetting pulses. The modification also improved prediction performance for net $\mathrm{N}$ mineralization in treatments with shorter rewetting intervals, but did not improve predictions in treatments with longer rewetting intervals. The model modifications were validated by using a laboratory incubation data set from a different field site. The modified DAYCENT predictions showed that active and slow SOM pools were major contributors to mineralization pulses while the contribution from the passive pool was minimal. The modifications we made improved model performance and should be considered in future field representations of biogeochemical processes.
\end{abstract}

(C) 2010 Elsevier B.V. All rights reserved.

\section{Introduction}

Xeric ecosystems, such as those dominated by chaparral species, often experience abrupt shifts from dry to wet conditions due to variability in rainfall. Therefore, the influence of soil moisture on soil carbon $(\mathrm{C})$ and nitrogen $(\mathrm{N})$ dynamics is particularly important in arid and semi-arid ecosystems because the rapid rewetting of a dry soil can cause a large pulse in soil $\mathrm{C}$ and $\mathrm{N}$ mineralization rates (Birch, 1958; Borken and Matzner, 2009; Fierer and Schimel, 2002; Miller et al., 2005). After soil rewetting, $\mathrm{CO}_{2}$ production rates can be elevated by as much as $500 \%$ compared with samples kept continuously moist, with the $\mathrm{CO}_{2}$ pulse persisting for 2 to 6 days following the rewetting event (Fierer and Schimel, 2003). Borken and Matzner (2009) summarized mechanisms of $\mathrm{C}$ and $\mathrm{N}$ mineralization and fluxes in soils under drying and wetting effects. Accumulated microbial and plant necromass, lysis

\footnotetext{
* Corresponding author. State Key Laboratory of Urban and Regional Ecology, Research Center for Eco-Environmental Sciences, No.18 Shuangqing Road, Haidian District, Beijing 100085, China. Tel./fax: + 861064849428

E-mail address: xyli@rcees.ac.cn (X. Li).
}

of live microbial cells, release of compatible solutes and exposure of previously protected organic matter may explain the additional mineralization in soils. The organic substrates causing wetting effects may originate from different sources produced, accumulated or exposed during the drying period. $\mathrm{C}$ and $\mathrm{N}$ could be released from both microbial biomass and nonmicrobial substrates. $\mathrm{C}$ and $\mathrm{N}$ mineralization will increase during wetting with increasing pool of accessible $\mathrm{C}$ and $\mathrm{N}$ substrates (Borken and Matzner, 2009). A major question, however, has been how important these pulses are in overall $\mathrm{C}$ and $\mathrm{N}$ cycling through their effects on all active, slow and passive pools.

Quantitative relationships have been established between soil moisture status and $\mathrm{C}$ and $\mathrm{N}$ mineralization rates in previous studies (De Neve and Hofman, 2002; Goncalves and Carlyle, 1994; Myers et al., 1982; Stanford and Epstein, 1974), and various empirical functions have been used to describe the impact of soil moisture on mineralization. For example, De Neve and Hofman (2002) applied parabolic, logistic and Gaussian-type functions to explain the relationship between $\mathrm{N}$ mineralization rates and soil water content, percent water-filled pore space (\%WFPS) or water potential $(\mathrm{pF})$. These kinds of empirical functions are usually used in $\mathrm{C}$ and $\mathrm{N}$ 
biogeochemical models for quantifying the effect of soil moisture on respiration and mineralization fluxes.

Several studies have tried to quantify the $C$ and $N$ rewetting pulse that occurs on the order of days to weeks after a dry soil is rewetted (Cabrera, 1993; Franzluebbers et al., 2000; Inubushi and Wada, 1987). However, empirical equations from these studies have not been associated with the dynamics of $\mathrm{C}$ or $\mathrm{N}$ state variables of different soil organic matter (SOM) pools, and have not been incorporated into $\mathrm{C}$ and $\mathrm{N}$ biogeochmical models. For this reason, it has been argued that current biogeochemical models should do poorly under dryingrewetting dominated conditions (Lawrence et al., 2009; Schimel, 2001). This point is particularly important, since if rewetting only accelerates the release of active $C$ that is normally a small pool with a fast turnover, then rewetting pulses are unlikely to have long-term effects on soil $C$ dynamics. If on the other hand, rewetting also stimulates the release of slow or passive $C$, large pools with slower turnover, then rewetting pulses may play a significant role in regulating long-term $\mathrm{C}$ dynamics and $\mathrm{C}$ sequestration. Therefore, frequent drying-rewetting events could bring different SOM pools into a new steady state with $\mathrm{C}$ and $\mathrm{N}$ transformation rates.

The idea that rewetting pulses affect both short and long-term $\mathrm{C}$ dynamics is supported by an experimental study where rapid rewetting of a dry soil influenced soil $\mathrm{C}$ cycling in the short-term, by increasing the microbial mineralization of cytoplasmic solutes in the active organic pool, and in the longer-term, by decreasing the total amount of SOM physically protected within microaggregates based on laboratory incubation experiments (Fierer and Schimel, 2003). Also, recent modeling work at the field scale for the chaparral ecosystems of California suggested that both short and long-term influences of drying-rewetting pulses need to be considered in biogeochemical models when they are applied to xeric ecosystems (Li et al., 2006).

In this study, we added an empirical rewetting factor to better reflect $\mathrm{C}$ and $\mathrm{N}$ release pulses in multiple drying-rewetting cycles in a biogeochemical model, DAYCENT under laboratory controlled conditions. We addressed the following aspects: (1) developing the rewetting pulse representation and modifying the DAYCENT model for better representing the drying-rewetting pulse mechanisms; (2) validating the rewetting pulse representation using modified DAYCENT model and independent incubation data; (3) investigating how the rewetting pulse representation captured the $\mathrm{C}$ and $\mathrm{N}$ dynamics through multiple drying-rewetting cycles.

\section{Materials and methods}

\subsection{Drying-rewetting experiment for model development}

An incubation experiment was conducted to determine whether episodic stress alters the timing and magnitude of carbon and nitrogen release from rewetted soils using a series of control and rewetting treatment experiments on California chaparral soils (Miller et al., 2005).

Table 1

Laboratory incubation treatments.

\begin{tabular}{|c|c|c|c|c|}
\hline Treatment & \multirow[t]{2}{*}{ Substrate } & \multirow{2}{*}{$\begin{array}{l}\text { Rewetting interval } \\
\text { (weeks) }\end{array}$} & \multirow{2}{*}{$\frac{\text { Water hold }}{{\text { capacity }(\%)^{a}}^{a}}$} & \multirow{2}{*}{$\begin{array}{l}\text { Initial soil moisture } \\
(\%, \text { volumetric base })\end{array}$} \\
\hline Number & & & & \\
\hline Control1 & Soil & $\mathrm{N} / \mathrm{A}$ & 4 & 2.2 \\
\hline Control2 & Soil & $\mathrm{N} / \mathrm{A}$ & 8 & 4.3 \\
\hline Control3 & Soil & $\mathrm{N} / \mathrm{A}$ & 16 & 8.6 \\
\hline Control4 & Soil & N/A & 60 & 32.1 \\
\hline Control5 & Soil + litter & $\mathrm{N} / \mathrm{A}$ & 4 & 2.2 \\
\hline Control6 & Soil + litter & $\mathrm{N} / \mathrm{A}$ & 16 & 8.6 \\
\hline Control7 & Soil + litter & $\mathrm{N} / \mathrm{A}$ & 60 & 32.1 \\
\hline Rewet1 & Soil & 4 & 8 & 32.1 \\
\hline Rewet2 & Soil & 2 & 16 & 32.1 \\
\hline Rewet3 & Soil + litter & 2 & 16 & 32.1 \\
\hline
\end{tabular}

a Water hold capacity (WHC) here is defined as moisture content at saturation.
The top $10 \mathrm{~cm}$ of soil from under chamise canopy on a toe slope was collected for the experiment from the Chamise Creek watershed in the southwestern Sierra Nevada within Sequoia and Kings Canyon National Parks, California $\left(36^{\circ} 30^{\prime} 42^{\prime \prime} \mathrm{N}, 118^{\circ} 42^{\prime} 23^{\prime \prime} \mathrm{W}\right)$. Mean maximum and minimum temperatures at Ash Mountain, approximately $3 \mathrm{~km}$ from the study site, are 36.4 and $2.2^{\circ} \mathrm{C}$. Mean annual precipitation is $670 \mathrm{~mm}$, with the majority of rainfall occurring between November and April. The soil is an Ultic Haploxeralf (Huntington and Akeson, 1987), and is a sandy clay with a pH of 6.2 , SOM content of $6.6 \%$, and $\mathrm{C}$ and $\mathrm{N}$ contents of $2.3 \%$ and $0.1 \%$, respectively. The vegetation is dense chaparral dominated by Adenostema fasciculatum with subdominants of Cercocarpus betuloides, Ceanothus cuneatus and Eriodictyon californicum, and with an understory of sparse annual grasses. The watershed has not been burned for 43 years. The climate is variable from year to year with a typical Mediterranean-climate pattern, with short, wet winters and long, dry summers.

Surface soils $(0-10 \mathrm{~cm})$ were sieved to $4 \mathrm{~mm}$ and stored at $20^{\circ} \mathrm{C}$ and field moisture ( $4 \%$ of water-holding capacity (WHC)) until the initiation of the rewetting treatment. 100\% WHC from the gravimetric water content of soil that was saturated and then allowed to drain over 6 hours. The laboratory rewetting incubation experiment consisted of seven control and three rewet treatments (see Table 1), with rewetting treatment soils being wetted and dried at 2-week and 4-week intervals. This rewetting frequency is equivalent to eight and four rewetting events, respectively, over the 16-week experimental period, respectively. Each of the seven control treatments were maintained at one of following moisture levels over the course of the experiment: $4 \%, 8 \%, 16 \%$ or $60 \%$ of WHC. Rewetting treatments consisted of soils that were periodically brought to $60 \%$ WHC and then allowed to dry to $4 \%$ WHC over a period of 5-6 days. Rewetting frequencies of 2 and 4 weeks were used to simulate the natural range of storm frequency, as determined from local meteorological records (Sequoia and Kings Canyon National Parks, Division of Natural Resources, 1948-2002, unpublished data). Litter treatments (soil + litter) consisted of $2 \mathrm{mg} \mathrm{C/g}$ soil as Adenostema litter, equivalent to a $10 \%$ increase in soil $\mathrm{C}$ or a $10 \%$ increase in mean annual litterfall $\mathrm{C}$ (approximately $100 \mathrm{~g} \mathrm{~m}^{-2} \mathrm{y}^{-1}$ ). Litter was collected in August-September of 2002, air dried and ground to pass through a 40 mesh ( $420 \mu \mathrm{m})$ screen, and was added to soils prior to the start of the incubation experiment. The incubation experiment was conducted at a constant temperature $25^{\circ} \mathrm{C}$.

Net $\mathrm{N}$ mineralization and nitrification were determined by the differences between the initial (T0) and final (T1) inorganic N pools during incubation periods for each treatment in Table 1. Ten days (T0) following the start of the experiment and the first wetting-drying event, a subset of soils from each treatment was harvested for determination of initial inorganic $\mathrm{N}$ pools. Following a 16 -week incubation (T1), a subset of soils from each treatment was harvested for determination of final inorganic $\mathrm{N}$ pools, and net $\mathrm{N}$ mineralization and nitrification rates. Soils were harvested following the final wetting-drying event (T1), when rewet soils had returned to $4 \%$ WHC. During the entire incubation time period, only accumulated net $\mathrm{N}$ mineralization and nitrification were estimated. Soil respiration was measured on rewet soils at daily intervals during each rewetting event, beginning approximately $4 \mathrm{~h}$ following wet-up and continuing through the dry down period until soils again reached $4 \%$ WHC. Respiration rates in control soils were measured every 2 weeks. More details about the incubation experiment can be found in Miller et al. (2005).

\subsection{Dry rewetting experiment for model evaluation}

For model validation purposes, we used separate data from a different incubation experiment derived by (Xiang et al., 2008). The top $5 \mathrm{~cm}$ of soil was collected from a freshly exposed soil profile in a California grassland $\left(34^{\circ} 41^{\prime} 29.4^{\prime \prime} \mathrm{N} ; 120^{\circ} 02^{\prime} 42.7^{\prime \prime} \mathrm{W}\right)$ at the University of California Sedgwick Reserve in April 2006. The sampling site has a 
similar Mediterranean-climate pattern with above model development site. The soil is a Pachic Argiustoll. We used data from two treatments: (1) six cycles of rewetting events separated by 7-day dry periods (6C), and (2) twelve cycles where soils were rewet immediately upon drying (12C). One rewetting/drying cycle consisted of rewetting to $35 \%$ WHC and incubating moist for 3 days, followed by a 3-day dry-down period before soils were dried to 5\% WHC. The total incubation time 75 days in addition to the initial period following the initial dry down and pre-equilibration. The incubation temperature was constantly maintained at $20^{\circ} \mathrm{C}$. Carbon dioxide production was measured after the 3-day rewetting period for the multiple dry/wet cycle treatments, and at regular intervals for the continuously moist treatments. Both cumulative $\mathrm{CO}_{2}$ production and the immediate $\mathrm{CO}_{2}$ production rate over each time interval were calculated. Accumulated net $\mathrm{N}$ mineralization and nitrification during the incubation were measured and estimated in the same way in Miller et al. (2005). More details about the description of the incubation experiment for model validation can be found in Xiang et al. (2008).

\subsection{Model description}

The DAYCENT biogeochemical model (Del Grosso et al., 2001; Parton et al., 1998) is the daily time step version of the CENTURY model (Parton et al., 1994). DAYCENT and CENTURY both simulate the biogeochemical processes of $\mathrm{C}, \mathrm{N}$, phosphorus, and sulfur cycling associated with soil organic matter (SOM) dynamics for grasslands, agricultural lands, forests and savannas. In addition to modeling decomposition, nutrient flows, soil water, and soil temperature on a finer time scale than CENTURY, DAYCENT also has increased vertical resolution of soil layers. DAYCENT includes sub-models for plant productivity, decomposition of dead plant material and SOM, soil water and temperature dynamics, and trace gas fluxes. Required inputs to the model include daily maximum/minimum temperature and precipitation, site specific soil properties, and current and historical land use. Disturbances and management practices such as fire, grazing, cultivation, harvest, irrigation, and organic matter or fertilizer additions can be predicted. The daily outputs in the original DAYCENT codes include soil moisture, temperature, trace gases of $\mathrm{N}_{2} \mathrm{O}, \mathrm{NO}$, and $\mathrm{CH}_{4}$. We recently developed the daily outputs for stream flow, stream $\mathrm{NO}_{3}^{-}$export, net $\mathrm{N}$ mineralization, and soil $\mathrm{CO}_{2}$ for DAYCENT (Li et al., 2006). The detailed descriptions of model structure and functions for DAYCENT and its new daily outputs can be found in the literature (Del Grosso et al., 2001; Li et al., 2006; Parton et al., 1998).

\subsection{Site data sources for model development}

Before DAYCENT could be used to simulate the incubation experiment, we ran the model under field conditions to obtain the initial parameters for the incubation predictions (see section of Parameterization of Incubation Predictions). Field data required in DAYCENT include daily climate data, soil physical properties and external nutrient input. The long-term daily meteorological data used in our predictions were maximum temperature, minimum temperature and precipitation. These climate data (1949-2002) were collected from a meteorological station at Ash Mountain in Sequoia and Kings Canyon National Parks, $4 \mathrm{~km}$ from the Chamise Creek catchment. The soil parameters are listed in Table 2. Annual $\mathrm{N}$ deposition was set at $0.77 \mathrm{~g} \mathrm{~m}^{-2} \mathrm{y}^{-1}$, and the wet and dry $\mathrm{N}$ deposition was $0.28 \mathrm{~g} \mathrm{~m}^{-2} \mathrm{y}^{-1}$ and $0.49 \mathrm{~g} \mathrm{~m}^{-2} \mathrm{y}^{-1}$, respectively. Symbiotic and non-symbiotic $\mathrm{N}$ fixation were set at $0.2 \mathrm{~g} \mathrm{~m}^{-2} \mathrm{y}^{-1}$ and $0.1 \mathrm{~g} \mathrm{~m}^{-2} \mathrm{y}^{-1}$, respectively (Gray and Schlesinger, 1981; Kummerow et al., 1978). We assume that fires occur every 45 years based on expert opinion. The last observed fire at the study site occurred in 1960 . The system was predicted with field data and results were used to establish initial conditions ( $\mathrm{Li}$ et al., 2006).
Table 2

Initial biomass and soil parameters of the chaparral ecosystem.

\begin{tabular}{lll}
\hline Parameter & Values & Sources \\
\hline Initial soil carbon pools & & \\
$\quad$ Litter & $595 \mathrm{~g} \mathrm{C} \mathrm{m}^{-2}$ & Gray and Schlesinger, 1981 \\
$\quad$ Mineral soil & $3509 \mathrm{~g} \mathrm{C} \mathrm{m}^{-2}$ & Huntington and Akeson, 1987 \\
Initial C/N & & \\
$\quad$ Litter & 50.5 & \\
$\quad$ Mineral soil & 18.6 & \\
Initial biomass & & \\
$\quad$ Aboveground biomass & $630 \mathrm{~g} \mathrm{C} \mathrm{m}^{-2}$ & Rundel and Parsons (1979) \\
$\quad$ Belowground biomass & $378 \mathrm{~g} \mathrm{C} \mathrm{m}^{-2}$ & Kummerow et al. (1978) \\
Kummerow et al. (1977) & & \\
$\quad$ Root:shoot & 0.6 & Kummerow et al. (1978) \\
$\quad$ Nitrogen concentration & & \\
$\quad \mathrm{N}$ in leaves & $1.38 \mathrm{~g} \mathrm{~N} \mathrm{~m}^{-2}$ & Rundel and Parsons (1980) \\
$\quad \mathrm{N}$ in fine branch & $22.73 \mathrm{~g} \mathrm{~N} \mathrm{~m}^{-2}$ & \\
$\mathrm{~N}$ in large wood & $9.74 \mathrm{~g} \mathrm{~N} \mathrm{~m}^{-2}$ & \\
$\mathrm{~N}$ in fine root & $18.81 \mathrm{~g} \mathrm{~N} \mathrm{~m}^{-2}$ & \\
$\mathrm{~N}$ in coarse root & $2.35 \mathrm{~g} \mathrm{~N} \mathrm{~m}^{-2}$ & \\
\hline
\end{tabular}

\subsection{Site data sources for model evaluation}

The initial parameter values for the incubation predictions were obtained from a field prediction at the Sedgwick ranch site (Xiang et al., 2008). Through a long simulation (2006 years), DAYCENT was executed to reach steady state. We estimated initial parameter values for the simulation at the field condition from published studies. These parameter values are not required to be accurate ( Li et al., 2006) as they are recalculated during the long calibration run. We assigned these initial values as: carbon content in litter $264 \mathrm{~g} \mathrm{~m}^{-2}$, in mineral soil $2923 \mathrm{~g} \mathrm{~m}^{-2}$; C/N ratio in litter 10.7, in mineral soil 8.4 (Xiang et al., 2008); initial carbon content in aboveground live plant $97.4 \mathrm{~g} \mathrm{C} \mathrm{m}^{-2}$, belowground $43.6 \mathrm{~g} \mathrm{C} \mathrm{m}^{-2}$, root: shoot ratio 0.51 (Hooper, 1998) and initial nitrogen content in aboveground live plant $5.7 \mathrm{~g} \mathrm{~N} \mathrm{~m}^{-2}$, belowground $5.0 \mathrm{~g} \mathrm{~N} \mathrm{~m}^{-2}$, litter $2.0 \mathrm{~g} \mathrm{~N} \mathrm{~m}^{-2}$ (Eviner and Firestone, 2007). Final conditions from the 2006 year simulations were utilized as the initial conditions for the model evaluation simulations using the laboratory incubation study of Xiang et al. (2008) since soil samples were taken in 2006.

\subsection{Parameterization of incubation predictions}

We derived the initial parameter values for the incubation predictions from a field prediction at the Chamise Creek site. This step is important because the incubation prediction requires initial parameter values at the time when we took incubation samples and the location where the samples were taken from. Another issue is the system cannot reach steady state status within short prediction time periods. The initial biomass and soil biogeochemical parameters for the Chamise watershed were estimated from literature or observed data (Table 2). Through a long run (2002 years), DAYCENT was executed to reach steady state of the modeled field chaparral ecosystem. September of 2002 was the time when soil samples were taken. The outputs of soil organic matter (SOM) pool sizes and $C$ to $\mathrm{N}$ ratios in September of 2002 were used as their parameter values of the incubation predictions (Table 3). In the control soil treatment (without litter addition), the ratio among different SOM pools are as follows: active SOM: slow SOM: passive $\mathrm{SOM}=1$ : 17.5 : 7.5 , and $\mathrm{C} / \mathrm{N}$ ratio is $20.0,31.3$ and 16.2 , respectively. In the litter addition treatment, we set the added litter as a soil litter pool (Table 3 ). In all rewetting treatments, each water addition was treated as a precipitation event.

In the incubation predictions, all of the plant $C$ pools were set to 0.0 with the exception of the large wood biomass parameter, which was set to $5000 \mathrm{~g} \mathrm{C} / \mathrm{m}^{2}$. Although there was no tree growth during the incubation prediction, the large wood biomass needed to be included 
Table 3

Initial parameter values of soil organic matter pools and their $\mathrm{C} / \mathrm{N}$ ratios for the incubation simulation.

\begin{tabular}{|c|c|c|}
\hline \multirow[t]{2}{*}{ Parameter } & \multicolumn{2}{|c|}{ Treatment } \\
\hline & Soil & Soil + litter \\
\hline Active soil organic matter pool: $\mathrm{g} \mathrm{C}^{-2}$ & 146.6 & 146.6 \\
\hline Slow soil organic matter pool: $\mathrm{g} \mathrm{C} \mathrm{m}^{-2}$ & 2567.6 & 2567.6 \\
\hline Passive soil organic matter pool: $\mathrm{g} \mathrm{C} \mathrm{m}^{-2}$ & 1072.4 & 1072.4 \\
\hline $\mathrm{C} / \mathrm{N}$ ratio of active soil organic matter pool & 20.0 & 20.0 \\
\hline $\mathrm{C} / \mathrm{N}$ ratio of slow soil organic matter pool & 31.3 & 31.3 \\
\hline $\mathrm{C} / \mathrm{N}$ ratio of passive soil organic matter pool & 16.2 & 16.2 \\
\hline Soil litter pool: $\mathrm{g} \mathrm{C} \mathrm{m}^{-2}$ & 0.0 & 170.6 \\
\hline $\mathrm{C} / \mathrm{N}$ ratio of soil litter pool & 50.0 & 50.0 \\
\hline
\end{tabular}

These parameters are obtained from the 3rd week outputs in September 2002 after a 2002 year simulation to reach equilibrium.

to provide the shading effect required to keep the soil surface temperature unchanged during the prediction.

\subsection{Calculation of rewetting factor}

We hypothesized that the incorrect estimations of $\mathrm{C}$ and $\mathrm{N}$ mineralization rates during rewetting were caused by the lack of a representation of rewetting pulses in DAYCENT in our application of DAYCENT to Chamise Creek (Li et al., 2006). In order to capture the drying-rewetting pulses in DAYCENT, a rewetting factor $(R)$ was developed to modify the moisture factor. The rewetting factor is defined as the increased effect of the drying-rewetting transition on the moisture factor beyond the normal impact of soil moisture. The original moisture factor is a coefficient that represents the soil moisture effect on SOM deposition (Parton et al., 2001). It is calculated as:

$W=\left(\left(\frac{W_{F P S}-b}{a-b}\right)^{d \cdot \frac{b-a}{a-c}}\right) \cdot\left(\left(\frac{\text { WFPS }_{i}-c}{a-c}\right)^{d}\right)$

where $W$ is moisture factor (value varies from 0 to 1 ), $a, b, c, d$ are coefficients that are influenced by soil texture, and $W F P S_{i}$ is waterfilled pore space on day $i$.

$W F P S_{i}=\frac{W_{\mathrm{g}} \cdot D_{\mathrm{b}}}{1-\frac{D_{\mathrm{b}}}{D_{\mathrm{p}}}}$

where $W_{\mathrm{g}}$ is soil gravimetric water content, $D_{\mathrm{b}}$ is soil bulk density, and $D_{\mathrm{p}}$ is soil particle density.

The rewetting factor was built on the basis of the relationship between increased $\mathrm{CO}_{2}$ release rate and incubation days after each rewetting event. Using the data from the 4 month rewetting incubation treatments (treatment "control 4", "rewet1" and "rewet2"), a first order equation was developed to represent the rewetting factor (Fig. 1):

$R=A \cdot e^{(-B \cdot T)}$

where $R$ is the rewetting factor (value varies from 0 to $A$ ), $T$ is incubation time (days) within each rewetting event since the initial rewetting date. $A$ is the increased proportion of SOM decomposition by the rewetting stimulation compared to SOM decomposition with constant soil moisture content at the initial rewetting date. We assumed that the SOM decomposition rate is proportional to the respiration rate. In our incubation experiment, parameter $A$ was calculated as the difference of respiration rate between the rewetting treatment at each initial rewetting date and the control treatment with constant soil moisture content at the initial rewetting date, and then divided by the respiration rate in the control treatment.

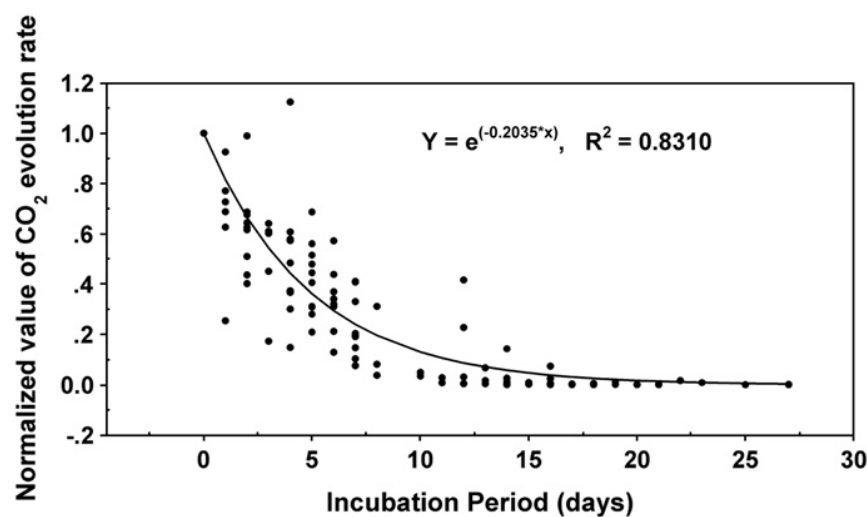

Fig. 1. The change of normalized value of observed $\mathrm{CO}_{2}$ evolution rate with incubation time. Normalized value of $\mathrm{CO}_{2}$ evolution rate refers to the ratio of $\mathrm{CO}_{2}$ evolution rate at any calculated point divided by the value at initial date of the rewetting event (see Fig. 2). Data that were used to fit the equation were from incubation treatment "rewet1", "rewet2" and "rewet3"( see Table 1).

Parameter $A$ represented a fraction of how much enhancement of SOM decomposition during a rewetting event that could not be represented in the original moisture factor. The constant soil moisture is $60 \%$ WHC in our experiment. $B$ is a rate constant. From the incubation data, we derived $A=2.99, B=0.2035$ (Figs. 1 and 2).

Then, the modified soil moisture factor $W^{\prime}$ was indicated as:

$W^{\prime}=W+R$

To calculate carbon flow in DAYCENT, the modified soil moisture factor $W^{\prime}$ was incorporated into the following equations:

$$
\begin{aligned}
& d C_{i} /_{d t}=C_{i} \cdot K_{i} \cdot W^{\prime} \cdot T_{s} \cdot P \cdot e^{\left(-3 L_{s}\right)}(i=1,2) \\
& d C_{i} /_{d t}=C_{i} \cdot K_{i} \cdot W^{\prime} \cdot T_{s} \cdot T_{m}(i=3) \\
& d C_{i} /_{d t}=C_{i} \cdot K_{i} \cdot W^{\prime} \cdot T_{s}(i=4,5,6,7,8)
\end{aligned}
$$

where $C_{i}=$ the carbon in state variable; $i=1,2,3,4,5,6,7,8$ for surface and soil structural materal, active SOM, surface microbes, surface and soil metabolic material, slow and passive SOM fractions; $W^{\prime}=$ modified soil moisture factor; $T_{s}=$ soil temperature factor; $P=\mathrm{pH}$ effect on decomposition; $T_{m}=$ effect of soil texture on active SOM turnover; $L_{s}=$ lignin content of structural material; $K_{i}=$ maximum decomposition rate for the $i$ th state variables $\left(K_{i}=3.9,4.9,7.3,6.0,14.8,18.5,0.2\right.$, 0.045 year $^{-1}$ ).

\subsection{Statistical analyses}

Model prediction error was indicated with the sum of squared residuals (SS), which is calculated by

$S S=\sum\left(y_{i}-\hat{y}_{i}\right)^{2}$

where $y_{i}$ is observed value and $\hat{y}_{i}$ is predicted value. The proportionate reduction in error by the model modification was calculated by

$R R=\frac{S S_{0}-S S_{1}}{S S_{0}} \times 100 \%$

where $R R$ is the proportionate reduction in error. $S S_{0}$ is the sum of squared residuals produced by the unmodified model and $S S_{1}$ is the sum of squared residuals produced by the modified model. 

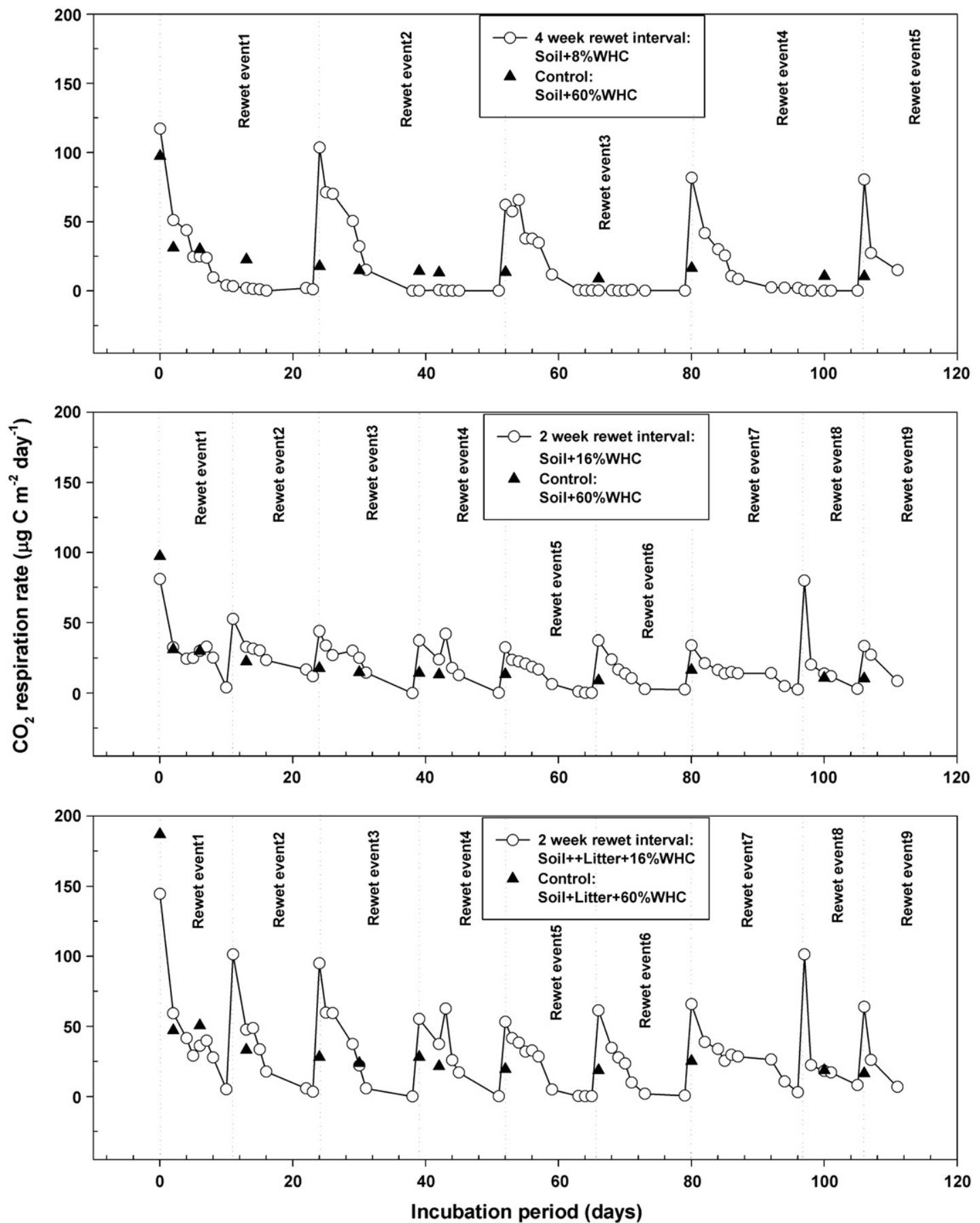

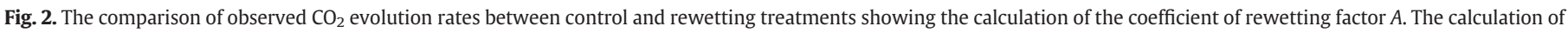

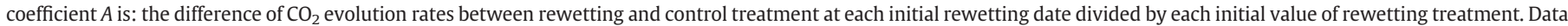
that were used to calculate coefficient A were from incubation treatment "control4", "rewet1", "rewet2" and "rewet3" (see Table 1).

\section{Results}

\subsection{Model predictions for soil respiration}

Since the rewetting factor $R$ in control treatments with constant soil moisture contents was 0 , the model modification did not change the predictions for any of the control treatments.

In all control treatments, unmodified DAYCENT overall was capable of reflecting the average level of $\mathrm{CO}_{2}$ release rate under different water holding capacities, but fluctuations in respiration observed in the incubated soils were not captured by the model
(Fig. 3). In the treatments with $60 \% \mathrm{WHC}$, the model captured the declining trend of $\mathrm{CO}_{2}$ release rate (Fig. 3).

In the incubation experiments, for a higher soil moisture level, respiration should consume more labile carbon. For example, the average $\mathrm{CO}_{2}$ release rate in the treatment of soil at $60 \% \mathrm{WHC}$ was as high as $14.2 \mu \mathrm{g} \mathrm{g} \mathrm{g}^{-1} \mathrm{day}^{-1}$, which was 226 fold higher than that in the treatment of soil at $4 \% \mathrm{WHC}$. The higher respiration rate apparently consumed labile $\mathrm{C}$, and as a result, the decline in the labile carbon pool caused a decrease in $\mathrm{CO}_{2}$ release at $60 \%$ WHC. In the treatments with medium soil moisture content (16\% WHC), a declining trend still existed during the incubation which was not captured by DAYCENT. 
Soil
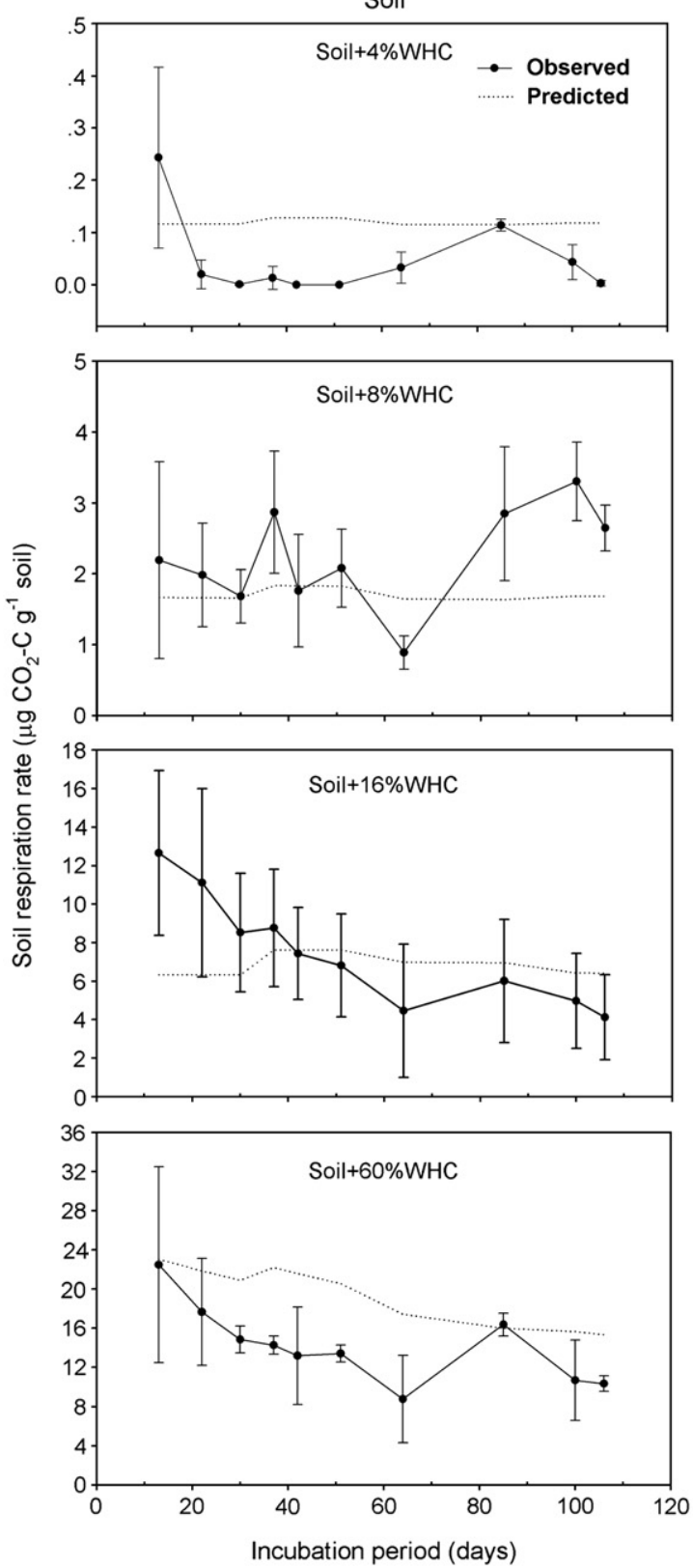

Soil + Litter

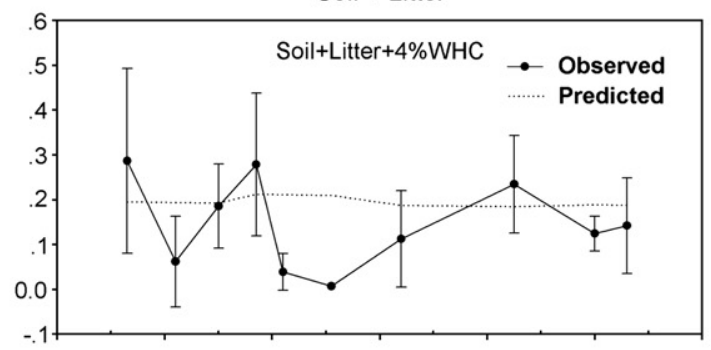

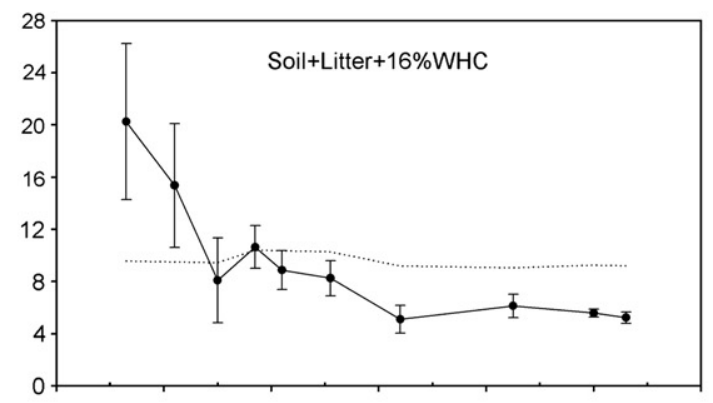

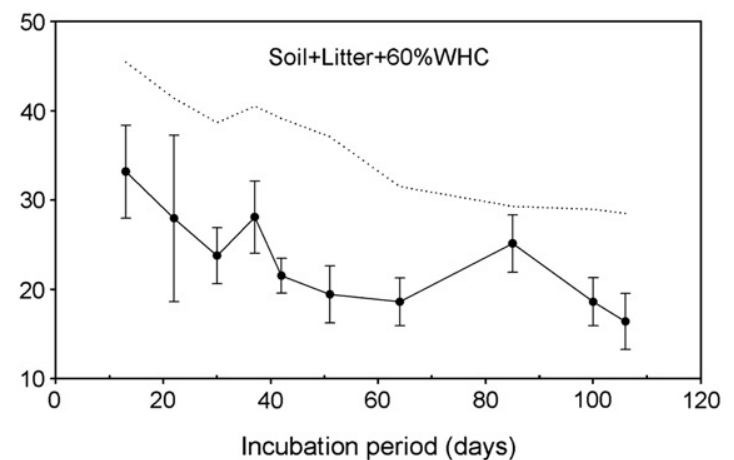

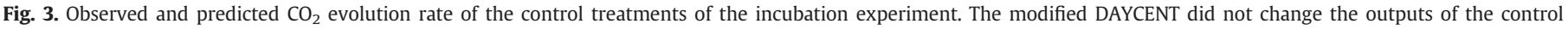

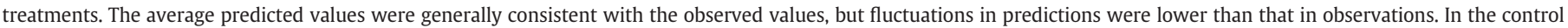
treatments with high water hold capacity $(\mathrm{WHC})$ values, the model captured the declining trend.

The litter addition increased the $\mathrm{CO}_{2}$ release rate in $4 \%, 16 \%$ and $60 \%$ WHC control treatments by $140 \%, 30 \%$ and $60 \%$, respectively. The model captured this increase (Fig. 3), but the impact of litter addition was less than the impact of changes in soil moisture. The model predictions at constant soil moisture content appeared to be inferior to the model predictions at fluctuating soil moisture (Figs. 3 and 4). This may not be a surprise. Since both temperature and soil moisture were constant in the control incubations, soil respiration rate should decline (in higher soil moisture treatments) or appear to be constant (in lower soil moisture treatments). The fluctuations in the control treatments could be explained by measurement errors and variations (Fig. 3).

The unmodified DAYCENT underestimated the rewetting pulses of $\mathrm{CO}_{2}$ release rate in all rewetting treatments (Fig. 4). In model predictions, each peak in respiration at each initial rewetting event represented a high level of respiration at a high level of soil moisture, but the transition effect from dry to wet was not represented. Unmodified DAYCENT underestimated $\mathrm{CO}_{2}$ release rate by $68 \%, 58 \%$ and $52 \%$ for the rewetting treatment of soil with each 4-week rewetting interval, soil with 2-week rewetting interval and soil plus litter with 2-week rewetting interval, respectively. In the incubation experiment, litter addition increased observed average $\mathrm{CO}_{2}$ release rate by 50\%; from $21.7 \mu \mathrm{g} \mathrm{C} \mathrm{g}^{-1}$ day $^{-1}$ to $32.8 \mu \mathrm{g} \mathrm{C} \mathrm{g}^{-1}$ day $^{-1}$. The DAYCENT predicted value also increased in the litter addition treatment, but the modeled increase was smaller than the observed increase.

The modified DAYCENT significantly improved the prediction of the rewetting pulses (Fig. 4). The prediction error was reduced by $51.5 \%, 71.2 \%$ and $70.3 \%$ for $\mathrm{CO}_{2}$ release in the rewetting treatment of a 4-week rewetting interval, 2-week interval and 2-week interval with litter addition, respectively (Table 4).

The observed average peak value of $\mathrm{CO}_{2}$ release rate decreased from $89.0 \mu \mathrm{g} \mathrm{C} \mathrm{g}^{-1}$ day $^{-1}$ to $48.0 \mu \mathrm{g} \mathrm{C} \mathrm{g}^{-1}$ day $^{-1}$ when the rewetting 


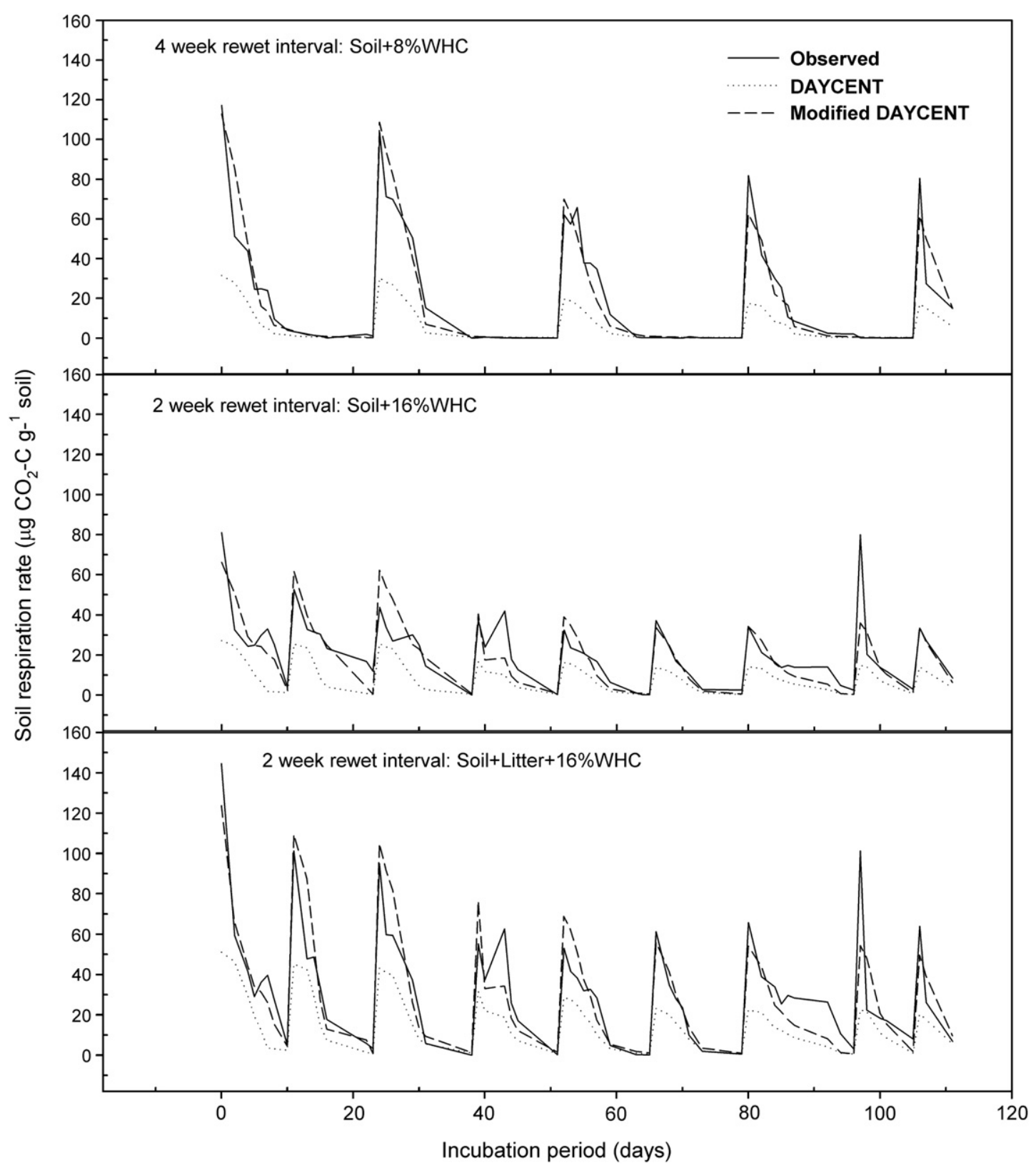

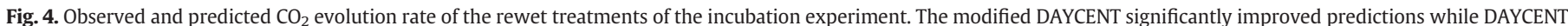
significantly under estimated $\mathrm{CO}_{2}$ evolution rate for each rewetting pulse.

interval decreased from 4 weeks to 2 weeks, and increased to $82.4 \mu \mathrm{g}$ $\mathrm{C} \mathrm{g}^{-1}$ day $^{-1}$ with litter addition under the 2 -week rewetting interval (Fig. 4). The increase in rewetting frequency had little effect on cumulative $\mathrm{CO}_{2}$ release (Table 5). Litter addition significantly enhanced cumulative $\mathrm{CO}_{2}$ release from $1348.4 \mu \mathrm{g} \mathrm{C} \mathrm{g}^{-1}$ day ${ }^{-1}$ to $2034.3 \mu \mathrm{g} \mathrm{C} \mathrm{g}^{-1} \mathrm{day}^{-1}$ (Table 5). While unmodified DAYCENT underestimated the influence of litter addition on $\mathrm{CO}_{2}$ release, the model modification captured this influence (Table 5).

Table 4

Reduced prediction errors (\%) by the model modification.

\begin{tabular}{llll}
\hline Number & Treatment & $\begin{array}{l}\mathrm{CO}_{2} \\
\text { respiration }\end{array}$ & $\begin{array}{l}\text { Net N } \\
\text { mineralization }\end{array}$ \\
\hline Rewet1 & Soil + 4 week rewet interval & 51.2 & None $^{\mathrm{a}}$ \\
Rewet2 & Soil + 2 week rewet interval & 71.2 & 95.2 \\
Rewet3 & Soil + litter + 2 week rewet interval & 70.3 & 98.4 \\
\hline
\end{tabular}

a The model modification did not reduce the prediction error for the simulation of the net $\mathrm{N}$ mineralization.

\subsection{Model predictions for $N$ mineralization and nitrification}

Overall, net $\mathrm{N}$ mineralization increased when soil moisture increased, and litter addition reduced net $\mathrm{N}$ mineralization during the 4 months incubation (Fig. 5 and Table 5). For example, cumulative net $\mathrm{N}$ mineralization was $5.0 \mu \mathrm{g} \mathrm{N} \mathrm{g}^{-1}$ for the treatment without litter addition at $4 \% \mathrm{WHC}$, little higher values at $8 \%$ and $16 \% \mathrm{WHC}$, but increased to $16.9 \mu \mathrm{g} \mathrm{N} \mathrm{g} \mathrm{N}^{-1}$ at $60 \%$ WHC. Litter addition decreased cumulative net $\mathrm{N}$ mineralization by $46 \%, 67 \%$ and $64 \%$ at $4 \%, 16 \%$ and $60 \%$ WHC. Unmodified DAYCENT correctly captured this trend, but overestimated $\mathrm{N}$ mineralization at $60 \%$ WHC. Our model modification did not change the predictions in all control treatments. For the rewetting treatments, observed cumulative net $\mathrm{N}$ mineralization increased by $553 \%$ when rewetting interval changed from 4 weeks to 2 weeks. Litter addition decreased net N mineralization by $25 \%$ at 2week rewetting interval treatment. While unmodified DAYCENT underestimated mineralization in all rewetting treatments, modified DAYCENT significantly improved their predictions (Fig. 5). For net $\mathrm{N}$ 
Table 5

Simulated cumulative net $\mathrm{N}$ mineralization and $\mathrm{CO}_{2}$ release from soil organic matter.

\begin{tabular}{|c|c|c|c|c|c|c|c|c|c|c|}
\hline \multirow[b]{2}{*}{ Treatment } & \multicolumn{5}{|c|}{ Cumulative net $\mathrm{N}$ mineralization from different SOM pools ${ }^{1} \mu \mathrm{g} \mathrm{N} \mathrm{g}^{-1}$ soil } & \multicolumn{5}{|c|}{ Cumulative $\mathrm{CO}_{2}$ release from different SOM pools $\mu \mathrm{g} \mathrm{C} \mathrm{g}^{-1}$ soil } \\
\hline & Litter & Active & Slow & Passive & Total & Litter & Active & Slow & Passive & Total \\
\hline \multicolumn{11}{|c|}{ Observations } \\
\hline Rewet1 & $\mathrm{N} / \mathrm{A}$ & $\mathrm{N} / \mathrm{A}$ & $\mathrm{N} / \mathrm{A}$ & $\mathrm{N} / \mathrm{A}$ & $6.0(2.2)^{2}$ & $\mathrm{~N} / \mathrm{A}$ & $\mathrm{N} / \mathrm{A}$ & $\mathrm{N} / \mathrm{A}$ & $\mathrm{N} / \mathrm{A}$ & $1291.1(283.7)^{2}$ \\
\hline Rewet2 & $\mathrm{N} / \mathrm{A}$ & $\mathrm{N} / \mathrm{A}$ & $\mathrm{N} / \mathrm{A}$ & $\mathrm{N} / \mathrm{A}$ & $39.4(5.2)$ & $\mathrm{N} / \mathrm{A}$ & $\mathrm{N} / \mathrm{A}$ & $\mathrm{N} / \mathrm{A}$ & $\mathrm{N} / \mathrm{A}$ & $1348.4(213.9)$ \\
\hline Rewet3 & $\mathrm{N} / \mathrm{A}$ & $\mathrm{N} / \mathrm{A}$ & $\mathrm{N} / \mathrm{A}$ & $\mathrm{N} / \mathrm{A}$ & $29.5(1.2)$ & $\mathrm{N} / \mathrm{A}$ & $\mathrm{N} / \mathrm{A}$ & $\mathrm{N} / \mathrm{A}$ & $\mathrm{N} / \mathrm{A}$ & $2034.3(228.1)$ \\
\hline \multicolumn{11}{|c|}{ DAYCENT simulations } \\
\hline Rewet1 & 0.0 & 5.9 & -0.6 & 0.0 & 5.4 & 0.0 & 220.8 & 192.3 & 1.8 & 415.0 \\
\hline Rewet2 & 0.0 & 20.2 & -1.2 & 0.1 & 19.1 & 0.0 & 291.4 & 267.6 & 2.5 & 561.5 \\
\hline Rewet3 & -0.7 & 16.8 & -1.9 & 0.1 & 14.3 & 183.3 & 168.0 & 134.4 & 1.3 & 487.0 \\
\hline \multicolumn{11}{|c|}{ Modified DAYCENT simulations } \\
\hline Rewet1 & 0.0 & 18.0 & -9.6 & 0.1 & 8.5 & 0.0 & 806.5 & 909.6 & 8.7 & 1724.7 \\
\hline Rewet2 & 0.0 & 64.2 & -29.4 & 0.3 & 35.1 & 0.0 & 828.2 & 1050.8 & 10.2 & 1889.1 \\
\hline Rewet3 & -8.3 & 68.5 & -29.0 & 0.2 & 31.4 & 601.2 & 1102.0 & 1162.6 & 11.2 & 2877.0 \\
\hline
\end{tabular}

Positive values indicate mineralization while negative values indicate immobilization. Numbers in parentheses indicate standard errors.

mineralization in rewetting treatments, modified DAYCENT reduced prediction error in the 2-week treatment without and with litter addition by $95 \%$ and $98 \%$, respectively, but slightly overestimated mineralization in the 4-week interval treatments.

Similar to the trends in mineralization, nitrification increased when soil moisture increased, but litter additions reduced net nitrification. Unmodified DAYCENT underestimated nitrification for all control treatments without litter addition, but slightly overestimated for control treatments with litter addition (Fig. 5). For the rewetting treatments, unmodified DAYCENT underestimated net nitrification. Modified DAYCENT increased prediction values for net nitrification in all rewetting treatments, but resulted in no improvement in the predictions except for the treatment of a 2-week interval without litter addition.

\subsection{Model evaluation}

Using the incubation experiments from the Sedgwick ranch soil experiment (Xiang et al., 2008) indicates that the modification made to the model for the Chamise Creek samples is transferable to other locations (Fig. 5). The type of ecosystem, the soils and the design and implementation of the incubation experiments differs significantly from the original experiments from (Miller et al., 2005). Modified DAYCENT was superior to the original DAYCENT for validations of soil carbon release and cumulative net $\mathrm{N}$ mineralization from both 12 and 6 rewetting cycle experiments (Fig. 6.). The original DAYCENT model under predicted higher respiration rate for both 12 and 6 rewetting cycle experiments while the modified model improved the performance (Fig. 6a \& b). The prediction performance of the original and modified models at the Chamise Creek site (Fig. 5c) has similar pattern with that at the Sedgwich ranch site. The modified model improved a lot in predicting cumulative net $\mathrm{N}$ mineralization while the model modification little under estimated $\mathrm{N}$ mineralization in 12 cycle experiment and overestimated in 6 cycle experiment (Fig. 6c).

\section{Discussion}

\subsection{Adding a rewetting factor improves explanation of overall $C$ and $N$ patterns}

We established a modified moisture factor and made the simple assumption that it applies to the decomposition rates of all $\mathrm{C}$ pools. The question was then whether this simple approach would adequately explain the overall dynamics of $\mathrm{C}$ and $\mathrm{N}$ in an experiment with episodic drying and rewetting. This experiment presented two surprising results that posed a test for the modified model: (1) the 2week and 4-week rewetting treatments released the same cumulative amount of $\mathrm{CO}_{2}$, despite average moisture contents differing by a factor of two, and (2) despite releasing very similar amounts of $\mathrm{C}$, net-N mineralization was significantly greater in the 2-week rewetting cycle than in the 4-week rewetting cycle soils. We then further tested our model modification with a completely different set of laboratory incubation experiments (Fig. 6). The results from these experiments further confirm the usefulness of the dry-rewetting model modification and show that the changes are likely suitable for a variety of conditions.

A simple single C-pool model would not be able to explain these apparently contradictory results. However, with just a simple modification, DAYCENT did an adequate job of capturing both the $\mathrm{C}$ and $\mathrm{N}$ dynamics through multiple drying-rewetting cycles. The modified DAYCENT reproduced both the amounts and timing of respiration (Fig. 4). The nitrogen results are more interesting and compelling. For the control treatments, DAYCENT reasonably predicted net $\mathrm{N}$ mineralization, except in the $60 \% \mathrm{WHC}+$ litter treatment, where it overestimated mineralization; it slightly overestimated mineralization in the 60\% WHC control as well. DAYCENT underestimated nitrification consistently in the minus-litter control treatments, but this is not a major failing. What is notable is that the modified DAYCENT model was able to accurately predict net $\mathrm{N}$ mineralization in the rewetting treatments, both with and without added litter. It accurately estimated the low net mineralization in the 4-week rewetting treatment and the high rates of $\mathrm{N}$ mineralization in the 2-week rewetting treatments. DAYCENT's ability to get the different $\mathrm{C}$ and $\mathrm{N}$ dynamics right lies in the balance of $\mathrm{C}$ and $\mathrm{N}$ pools and their differing mineralization/immobilization patterns.

\subsection{The rewetting factor impacts $\mathrm{C}$ and $\mathrm{N}$ releases from multiple SOM pools}

Previous studies have suggested that both microbial biomass and non-biomass $\mathrm{SOM}$ pools contribute to the rewetting $\mathrm{CO}_{2}$ pulse (Fierer and Schimel, 2003; Lawrence et al., 2009; Van Gestel et al., 1991; Vanveen et al., 1985). Fierer and Schimel (2003) suggested that the microbial biomass pool is the major contribution to the rewetting $\mathrm{CO}_{2}$ pulse in the short term, but the physically protected SOM will be more labile in the long term by the release of SOM from drying-rewetting events. After a rewetting factor was incorporated into DAYCENT, the model captured the rewetting $\mathrm{CO}_{2}$ pulse through increasing $\mathrm{CO}_{2}$ release from active and slow SOM pools and soil litter pool (Fig. 7). The $\mathrm{CO}_{2}$ release from the passive pool had minimal contribution. In the 4week rewetting interval treatment, compared with unmodified DAYCENT predictions, $\mathrm{CO}_{2}$ release in modified DAYCENT predictions from the active, slow and passive pool increased 2.7-fold, 3.7-fold and 3.8fold, respectively, accounting for $45 \%, 55 \%$ and $0.5 \%$ of the total increased contribution. In the 2-week rewetting interval treatment, the increase from active, slow and passive pool was 1.8-fold, 2.9-fold and 3.0 -fold, accounting for $40 \%, 59 \%$ and $0.6 \%$ of the total increased contribution. In the 2 -week rewetting interval with litter addition 


\section{a. Control: net $\mathrm{N}$ mineralization}

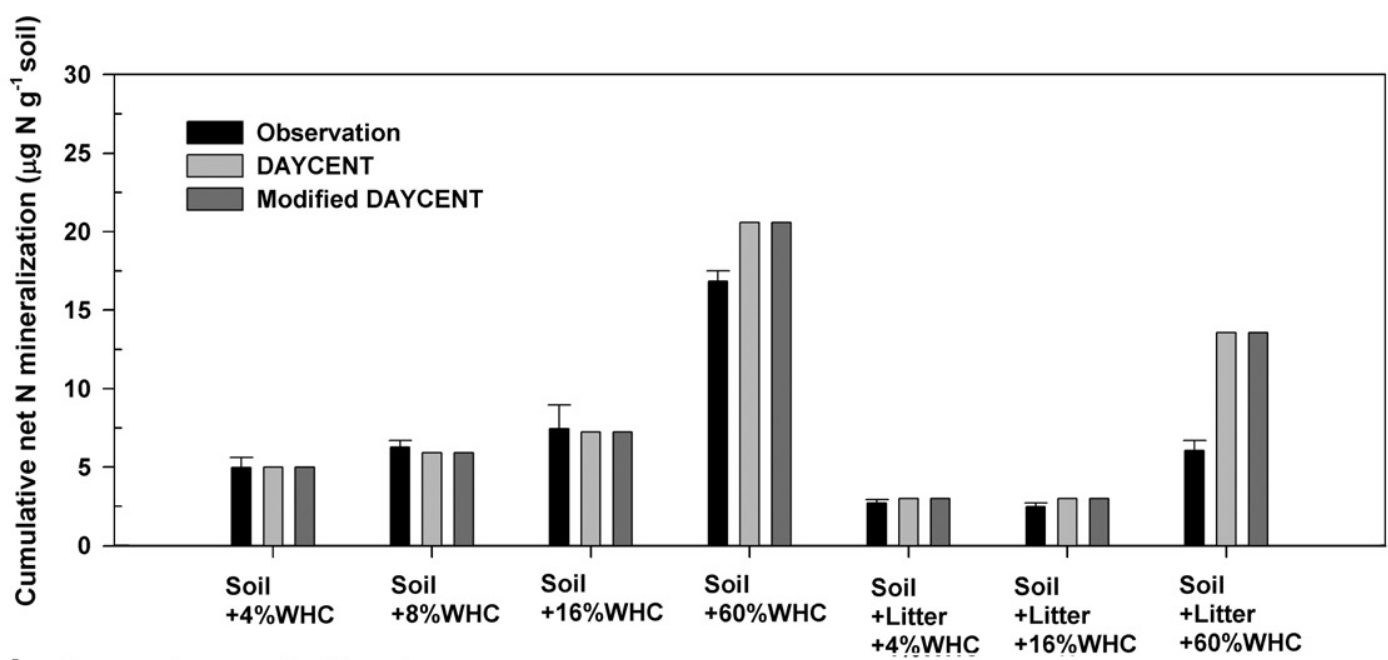

\section{b. Control: net nitrification}

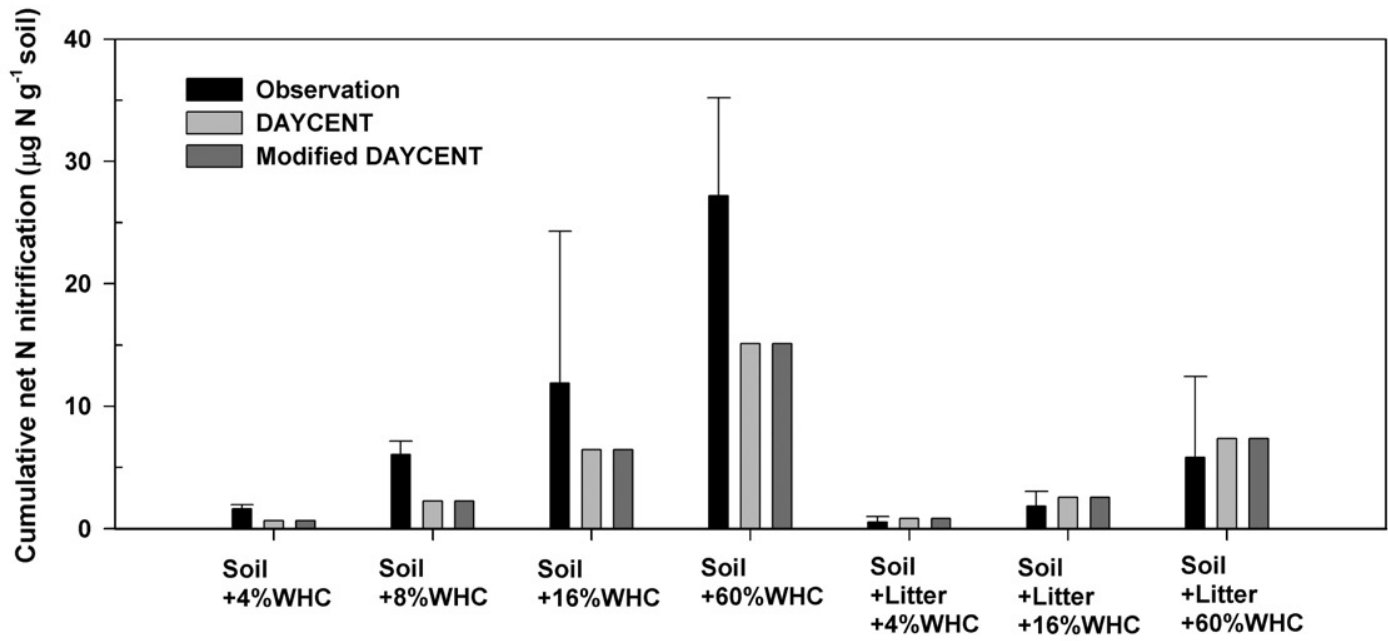

Control treatments

\section{Rewet: net $\mathbf{N}$} mineralization

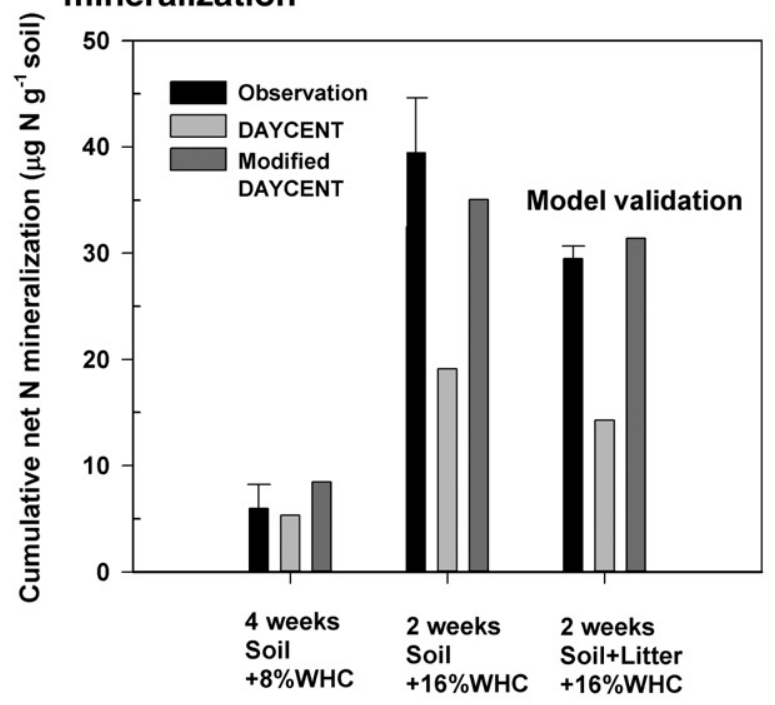

Rewet treatments d. Rewet: net nitrification

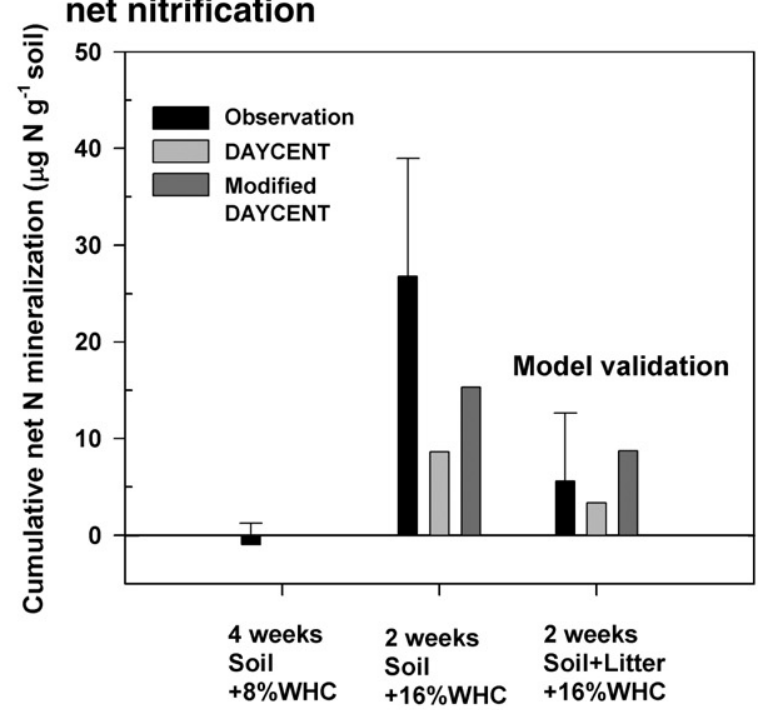

Rewet treatments

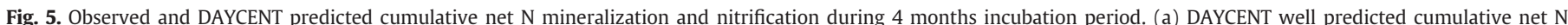

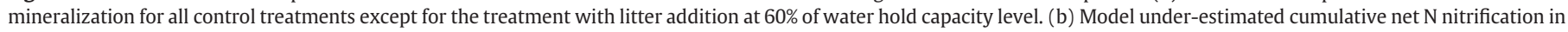

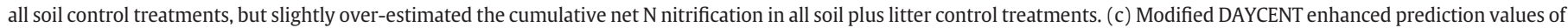
cumulative net $\mathrm{N}$ mineralization for all rewet treatments. (d) Modified DAYCENT significantly increased the predicted cumulative net $\mathrm{N}$ nitrification for all rewet treatments. 


\section{a. 12 drying-rewetting cycles}

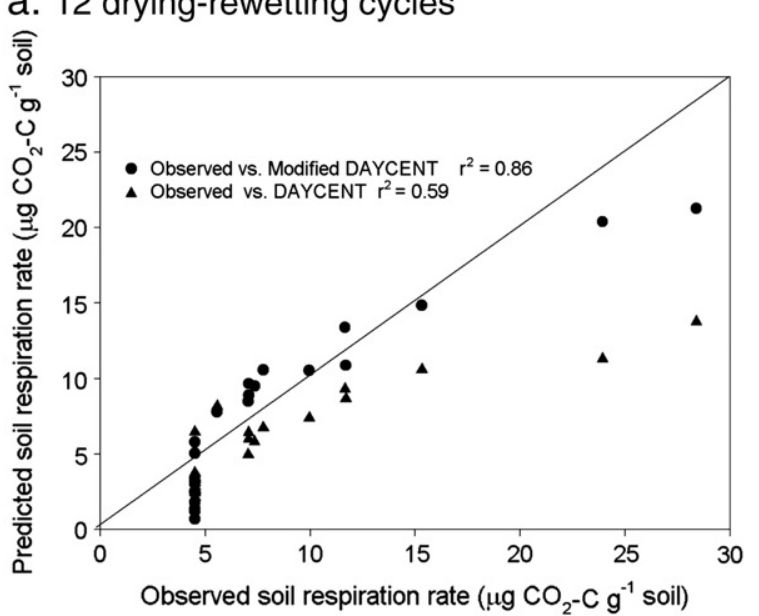

\section{b. 6 drying-rewetting cycles}

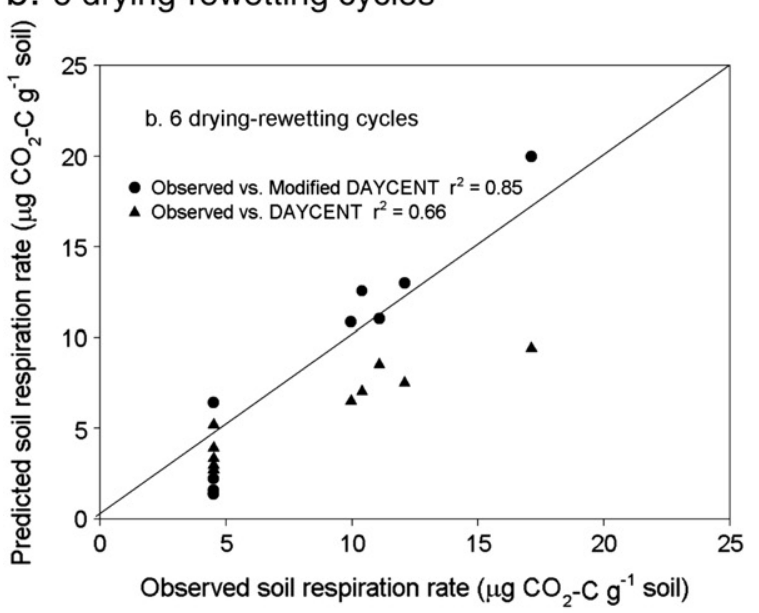

c. 12 \& 6 drying-rewetting cycles

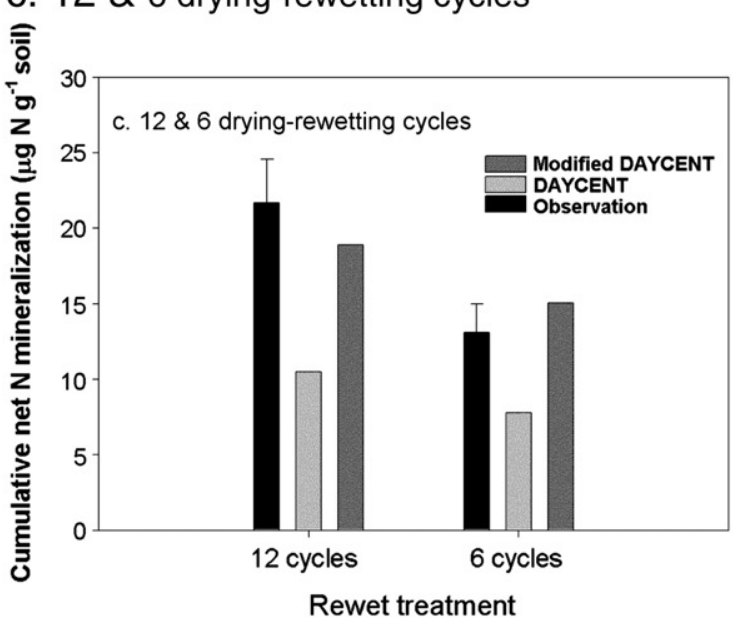

Fig. 6. Validation of modified DAYCENT: correlations between observed and model predicted soil respiration rate. Solid line is the 1:1 line. The soil samples were collected from California grassland data from Xiang et al. (2008). (a \& b) Observed verses original and modified DAYCENT predicted soil respiration rates for 12 and 6 drying-rewetting cycle treatments. (c) comparison among observed and original and modified DAYCENT predicted cumulative net $\mathrm{N}$ mineralization for 12 and 6 drying-rewetting cycle treatments.

treatment (validation data), the increase from soil litter, active, slow and passive pool was 2.3-fold, 5.6-fold and 7.7-fold, accounting for $17 \%, 39 \%, 43 \%$ and $0.4 \%$ of the total increased contribution. The incorporation of the rewetting factor reduced the $\mathrm{CO}_{2}$ release contribution from all pools when rewetting frequency was increased from one time to two times per month (Fig. 7). This change with rewetting frequency by rewetting modification in DAYCENT agreed with the deduction by Fierer and Schimel (2003): soils rarely exposed to drying and rewetting cycles will exhibit a larger $\mathrm{CO}_{2}$ pulse on rewetting than soils which are frequently dried and rewetted. The model modification captured the influence of litter amendment (Fig. 4). The enhancement of $\mathrm{CO}_{2}$ release by litter amendment in the modified DAYCENT prediction was produced by increases from all pools (Fig. 7). Although the rewetting factor incorporated in the model is exactly same for all SOM pools, it has very different effects on the $\mathrm{C}$ release from different SOM pools. We can easily understand different effects of the modified moisture factor from the calculation of $\mathrm{C}$ fluxes from different SOM pools in Eq. (5). In Eq. (5), eight $C$ pools are classified as three groups and their $C$ fluxes are calculated by three different equations. The difference of carbon content, decomposition rate, soil temperature, soil texture, soil $\mathrm{pH}$ and lignin content of structural material in different groups of $C$ pools change the effect of the same modified moisture factor on $C$ releases from different pools. The difference of the accessibility to micro-organisms should be already considered in the difference of carbon content, decomposition rate, soil texture. We ignored more details about the differences of the modified moisture factor effects within each group of SOM pools.

The model modification produced more complex results with $\mathrm{N}$ mineralization, since the respiration of the active pool contributes to net mineralization while the slow pool respiration immobilizes $\mathrm{N}$. Decomposition of the passive pool is too limited to have much effect over the time scale of this study (Fig. 7). Compared with unmodified DAYCENT predictions, the modified DAYCENT increased $\mathrm{N}$ mineralization from the active pool by $2-3$ fold, but increased immobilization into the slow pool by 15 - to 25 -fold. The net effects of the different pool dynamics caught the overall patterns of $\mathrm{N}$ mineralization. In the 4-week rewetting treatment, the absolute increases in mineralization from the active pool and immobilization into the slow pool were very similar in magnitude. Thus, modified DAYCENT predicted the limited increase in overall net mineralization with drying/rewetting that was observed in the data. In the case of the 2-week rewetting treatment, modified DAYCENT produced absolute increases in active fraction mineralization substantially greater than the increase in slow pool immobilization, thus producing a stimulation of overall net mineralization, as was observed in the data. In DAYCENT, N fluxes are linked with $\mathrm{C}$ fluxes through $\mathrm{C} / \mathrm{N}$ ratios. Each of the eight SOM pools (defined in Eq. (5)) has its own $\mathrm{C} / \mathrm{N}$ ratio value. The $\mathrm{N}$ flux value from each group of SOM pools is changed with the C flux value. The effect difference of modified moisture factor among three different group of $C$ pools (in Eq. (5)) causes difference of moisture effects on $\mathrm{N}$ dynamics. Therefore, adding the same simple rewetting factor can indirectly change $\mathrm{N}$ fluxes through its different effects on $\mathrm{C}$ fluxes and different $\mathrm{C} / \mathrm{N}$ ratios among SOM multiple pools.

One question that this modeling exercise does not address is the mechanism by which rewetting produces the pulses of microbial activity affecting the active and slow pools. The model highlights the importance of the slow pool in explaining differential mineralization results with different rewetting frequencies. This result is certainly consistent with the models proposed by Fierer and Schimel (2003), that there is some immediate release of $C$ on rewetting from microbial biomass (active pool) but that physical disruption also exposes physically protected, slow $C$ to attack. A combination of effects is certainly consistent with the extensive literature on drying/rewetting which has proposed release of microbial materials (Halverson et al., 2000; Kieft, 1987) and physical disruption of aggregates (Appel, 1998; Denef et al., 2001; Tisdall and Oades, 1982).

The value of the rewetting factor could be altered by several factors in the real environment, such as rewetting intensity, rewetting frequency, litter amendment or SOM quality. This study showed that the modified model could capture the influence of rewetting 

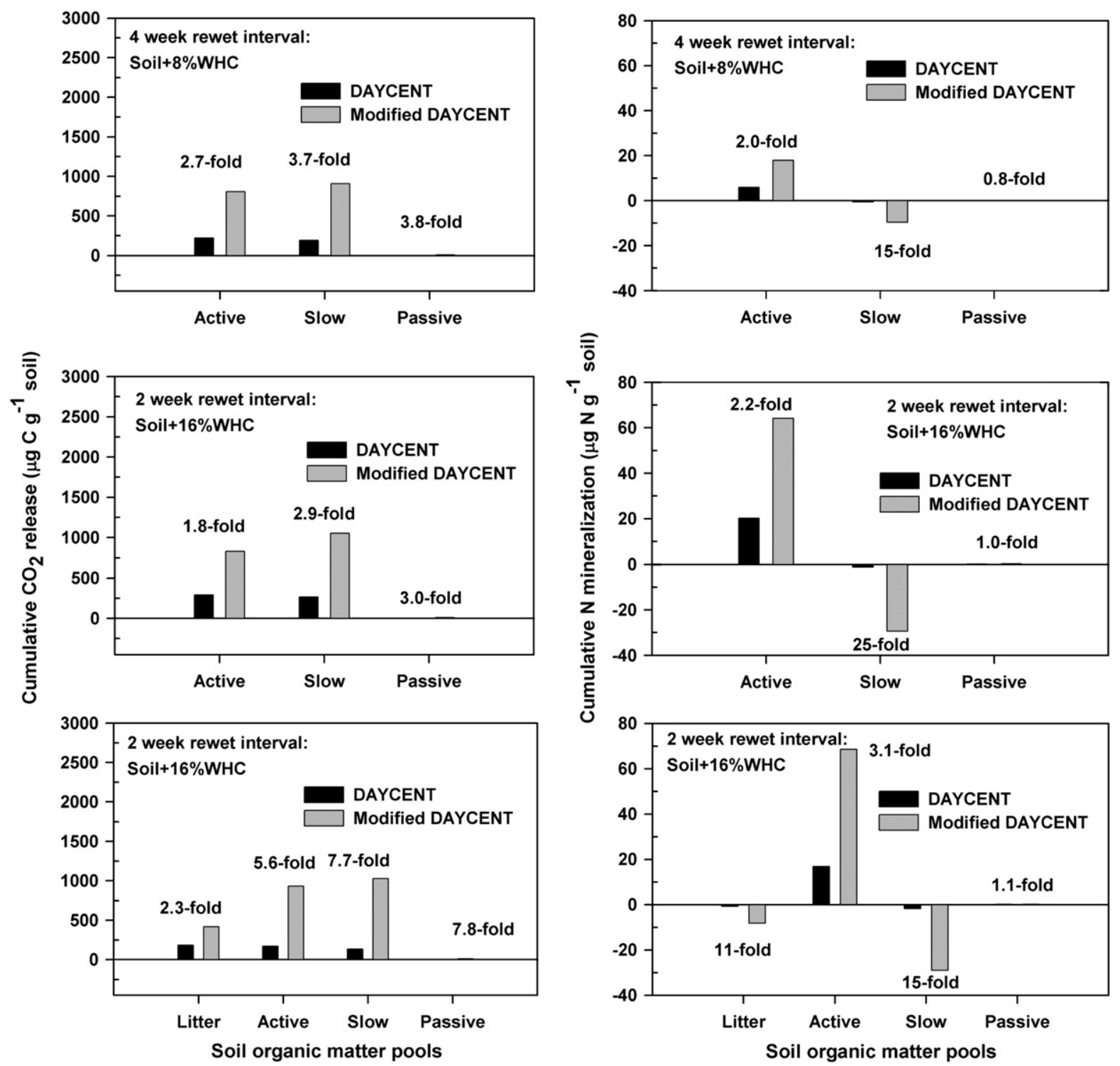

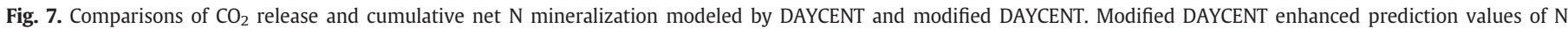

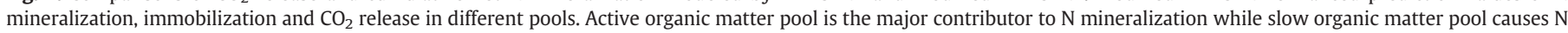

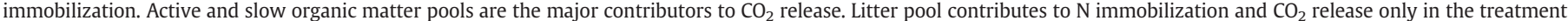
with the litter addition. The increases predicted with modified DAYCENT compared with DAYCENT are indicated for each pool.

frequency and litter addition, but the rewetting intensity or soil moisture difference between before and after a dry-rewetting event needs to be considered in the field application of our model modification. These factors need to be considered in the calibration when the model is applied to the field prediction.

\section{Conclusions}

In the DAYCENT biogeochemical model, the empirical equation with a direct relationship between moisture factor and soil moisture content failed to capture the rewetting pulses, which resulted in underestimation of $\mathrm{C}$ and $\mathrm{N}$ release from SOM in the context of dryingrewetting cycles. Based on a 16-week incubation experiment with treatments of different rewetting frequency and litter addition, the rewetting factor, a first-order dynamic equation $R=A \cdot e^{(-B \cdot T)}$ was developed to represent the increase of $\mathrm{CO}_{2}$ respiration rate stimulated by rewetting events of a dry soil vs. incubation days. The DAYCENT model was modified through incorporating the rewetting factor into the moisture factor. The rewetting consideration improved the simulations of $\mathrm{CO}_{2}$ respiration rate. More importantly, perhaps, incorporating the modified moisture factor allowed the modified DAYCENT to capture the complex $\mathrm{N}$ dynamics that were observed across the different drying-rewetting treatments. No single pool model could explain the different $\mathrm{N}$ mineralization dynamics in the different rewetting treatments. It is interesting and perhaps surprising that even a multi-pool model that applies the same modified moisture factor to all soil pools was able to capture these dynamics.

Clearly, the next step in the application of this model is to explore whether it can better capture the dynamics of $\mathrm{C}$ and $\mathrm{N}$ fluxes in the field, under different climate regimes. This application is important, as the climate in California (and other xeric regions as well) is extremely variable, with annual rainfall varying by as much as a factor of four. Wetting/drying cycles in the field do not necessarily follow the clean, reproducible pattern used in the experiment of Miller et al. (2005) and Xiang et al. (2008) that we used to develop the modified DAYCENT. However, its ability to reproduce complex dynamics under controlled conditions suggests that it should be a substantial improvement in describing ecosystem dynamics in rainfall-pulse-driven, arid and 
semi-arid ecosystems that are common around the globe and that are extremely sensitive to changing rainfall regimes associated with climate change.

\section{Acknowledgements}

We are grateful to Kevin Skeen for his assistance of field data collection, and Annie Esperanza for providing climate data. We thank Cindy Keough for her assistance with parameter estimation of the DAYCENT model. Funding was supported by the US National Science Foundation (Grant No. DEB-008939), the State Key Development Program for Basic Research of China (Grant No. 2009CB421104) and State Key Laboratory of Urban and Regional Ecology project (SKLURE2008-1-05) in China.

\section{References}

Appel, T., 1998. Non-biomass soil organic N-the substrate for $\mathrm{N}$ mineralization flushes following soil drying-rewetting and for organic $\mathrm{N}$ rendered $\mathrm{CaCl} 2$-extractable upon soil drying. Soil Biology \& Biochemistry 30 (10-11), 1445-1456.

Birch, H.F., 1958. The effect of soil drying on humus decomposition and nitrogen availability. Plant and Soil $10(1), 9-31$.

Borken, W., Matzner, E., 2009. Reappraisal of drying and wetting effects on C and N mineralization and fluxes in soils. Global Change Biology 15 (4), 808-824.

Cabrera, M.L., 1993. Modeling the flush of nitrogen mineralization caused by drying and rewetting soils. Soil Science Society of America Journal 57 (1), 63-66.

De Neve, S., Hofman, G., 2002. Quantifying soil water effects on nitrogen mineralization from soil organic matter and from fresh crop residues. Biology and Fertility of Soils 35 (5), 379-386.

Del Grosso, S.J., et al., 2001. Simulated interaction of carbon dynamics and nitrogen trace gas fluxes using the DAYCENT model. Modeling carbon and nitrogen dynamics for soil management 303-332.

Denef, K., et al., 2001. Influence of dry-wet cycles on the interrelationship between aggregate, particulate organic matter, and microbial community dynamics. Soil Biology \& Biochemistry 33 (12-13), 1599-1611.

Eviner, V.T., Firestone, M.K., 2007. Nutrient dynamics in California annual grasslands. In: Stromberg, M., Corbin, J., Antonio, C.D. (Eds.), Ecology and Management of California Grasslands, pp. 94-106.

Fierer, N., Schimel, J.P., 2002. Effects of drying-rewetting frequency on soil carbon and nitrogen transformations. Soil Biology \& Biochemistry 34 (6), 777-787.

Fierer, N., Schimel, J.P., 2003. A proposed mechanism for the pulse in carbon dioxide production commonly observed following the rapid rewetting of a dry soil. Soil Science Society of America Journal 67 (3), 798-805.

Franzluebbers, A.J., Haney, R.L., Honeycutt, C.W., Schomberg, H.H., Hons, F.M., 2000 Flush of carbon dioxide following rewetting of dried soil relates to active organic pools. Soil Science Society of America Journal 64 (2), 613-623.

Goncalves, J.L.M., Carlyle, J.C., 1994. Modelling the influence of moisture and temperature on net nitrogen mineralization in a forested sandy soil. Soil Biology and Biochemistry 26 (11), 1557-1564.

Gray, J.T., Schlesinger, W.H., 1981. Biomass, production, and litterfall in the coastal sage scrub of Southern-California. American Journal of Botany 68 (1), 24-33.

Halverson, L.J., Jones, T.M., Firestone, M.K., 2000. Release of intracellular solutes by four soil bacteria exposed to dilution stress. Soil Science Society of America Journal 64 (5), 1630-1637.
Hooper, D.U., 1998. The role of complementarity and competition in ecosystem responses to variation in plant diversity. Ecology 79 (2), 704-719.

Huntington, G.L. and Akeson, M.A., 1987. Soil Resource Inventory of Sequoia National Park, Central Part, California. U.S. Dept. of Interior, National Park Service, CA Order No. 8005-2-0002.

Inubushi, K., Wada, H., 1987. Easily decomposable organic-matter in paddy soils. 7. Effect of various pretreatments on N-mineralization in submerged soils. Soil Science and Plant Nutrition 33 (4), 567-576.

Kieft, T.L., 1987. Microbial biomass response to a rapid increase in water potential when dry soil is wetted. Soil Biology and Biochemistry 19 (2), 119-126.

Kummerow, J., Alexander, J.V., Neel, J.W., Fishbeck, K., 1978. Symbiotic nitrogen fixation in Ceanothus roots. American Journal of Botany 65 (1), 63-69.

Lawrence, C.R., Neff, J.C., Schimel, J.P., 2009. Does adding microbial mechanisms of decomposition improve soil organic matter models? A comparison of four models using data from a pulsed rewetting experiment. Soil Biology \& Biochemistry 41 (9), 1923-1934.

Li, X., et al., 2006. Decadal-scale dynamics of water, carbon and nitrogen in a California chaparral ecosystem: DAYCENT modeling results. Biogeochemistry 77 (2), 217-245.

Miller, A.E., Schimel, J.P., Meixner, T., Sickman, J.O., Melack, J.M., 2005. Episodic rewetting enhances carbon and nitrogen release from chaparral soils. Soil Biology and Biochemistry 37 (12), 2195-2204.

Myers, R.J.K., Campbell, C.A., Weier, K.L., 1982. Quantitative relationship between net nitrogen mineralization and moisture content of soils. Canadian Journal of Soil Science 62 (1), 111-124

Parton, W.J., Ojima, D.S., Cole, C.V., Schimel, D.C., 1994. A general model for soil organic matter dynamics: sensitivity to litter chemistry, texture and management. In: Quantitative Modeling of Soil Forming Processes (Special Pub. 39). Soil Science Society of America, Madison, Wisconsin, pp. 147-167.

Parton, W.J., Hartman, M., Ojima, D., Schimel, D., 1998. DAYCENT and its land surface submodel: description and testing. Global and Planetary Change 19 (1), 35-48.

Parton, W.J., et al., 2001. Generalized model for NOx and N20 emissions from soils. Journal of Geophysical Research 106 (D15), 17403-17420.

Rundel, P.W., Parsons, D.J., 1979. Structural changes in chamise (Adenostoma fasciculatum) along a fire induced age gradient. Journal of Range Management 32, 462-466.

Rundel, P.W., Parsons, D.J., 1980. Nutrient changes in two chaparral shrubs along a fireinduced age gradient. American Journal of Botany 67, 51-58.

Schimel, J.P., 2001. Biogeochemical models: implicit vs. explicit microbiology. In: Schulze, E., Heimann, M., Harrison, S., Holland, E., Lloyd, J., Prentice, I., Schimel, D. (Eds.), Global Biogeochemical Cycles in the Climate System, pp. 177-183.

Stanford, G., Epstein, E., 1974. Nitrogen mineralization-water relations in soils. Soil Science Society of America Journal 38 (1), 103-107.

Tisdall, J.M., Oades, J.M., 1982. Organic-matter and water-stable aggregates in soils. Journal of Soil Science 33 (2), 141-163.

Van Gestel, M., Ladd, J.N., Amato, M., 1991. Carbon and nitrogen mineralization from two soils of contrasting texture and microaggregate stability: influence of sequential fumigation, drying and storage. Soil Biology and Biochemistry 23 (4), 313-322.

Vanveen, J.A. Ladd, J.N., Amato, M. 1985. Turnover of carbon and nitrogen through the microbial biomass in a sandy loam and a clay soil incubated with [C-14(U)] glucose and [N-15] (Nh4)2so4 under different moisture regimes. Soil Biology \& Biochemistry 17 (6), 747-756.

Xiang, S.R., Doyle, A., Holden, P.A., Schimel, J.P., 2008. Drying and rewetting effects on C and $\mathrm{N}$ mineralization and microbial activity in surface and subsurface California grassland soils. Soil Biology \& Biochemistry 40 (9), 2281-2289. 